أبحاث المؤتمر العلمي الدولي الثاني / نقابة

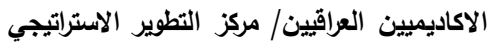

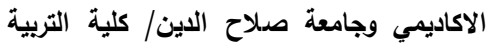

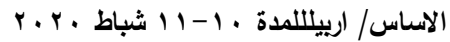

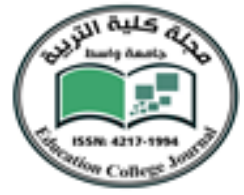

جامعة واسط

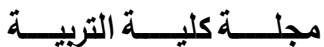

\title{
Social Injustice and Discrimination in Lessing's \\ Going Home
}

Assist. Inst. Mohammed Burhan Kakakhan

College of Languages \& Human Sciences

University of Garmian-Kurdistan

ABSTRACT

Email: mohammed.kakakhan@garmian.edu,krd

Having a deep, emotional, memorial with a country where everyone's main concern was politics all the time, Doris Lessing is seemingly politicallyminded.

Going Home, which is an account of her return to Rhodesia (Zimbabwe), shows a clear view of Lessing's declared opposition to illiberal white rule. This paper explores the social structure of Rhodesia at that time. Southern Rhodesia structure was based on oppression, an oppression based purely on race. Once Lessing returns to her native land she again observes, reports the bloody-minded whites to accept the black as humans. Lessing claims that due to her attitude to abolish the white rules in Africa she was declared to be a Prohibited Immigrant. Thus, Going Home can be read as bifocally both as an experience of a nation with persecution and her own experience with exile.

Keywords: Oppression, color- bar, federation, exile

كاتبة لديها في كتاباتها ولع للوطن الام طوال الوقت ، تبدو دورس ليسينغ ذات تفكير سياسي في

رواياتها.

ثُظهر رواية العودة إلى الوطن ، وهي رواية عن عودتها إلى روديزا (زيمبابوي) ، رؤية واضحة

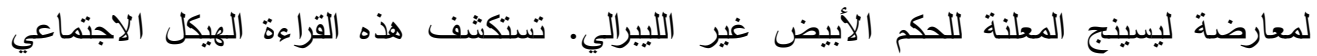
لروديزا في ذلك الوقت. اعتمد هيكلية منطقة روديزا الجنوبية على الاضطهاد ، وهو اضطهاد قائم

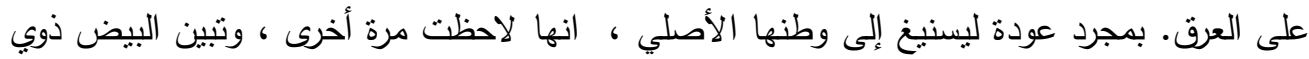

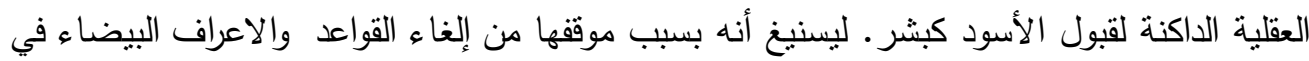

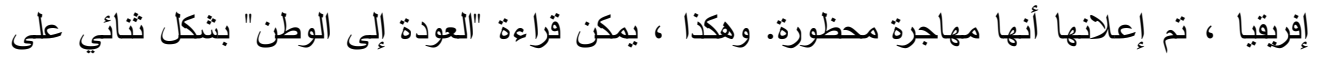
حد سواء كتجربة لأمة تعاني من الاضطهاد وتجربة خاصة بها مع المنفى. 

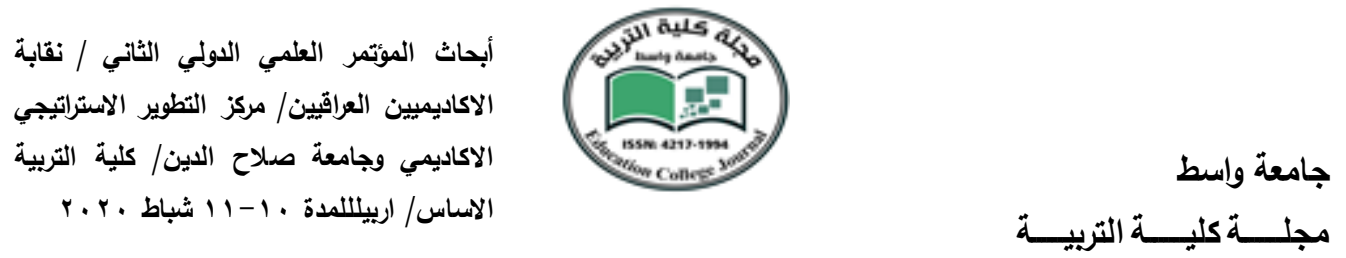

\section{Introduction}

\section{A Short Historical Background of Southern Africa (Rhodesia):}

In Zimbabwe, as in all places in Africa, the history of black struggle against white minority rule was a long one. Zimbabweans tie the beginning of their confrontation to white rule in the 1890's when their ancestors rose against the first white settlers to try stop them from settling on their land (Sibanda 1). It is worthy to note that "Rhodes believed that the English had an inherent right to imperial rule because they were the first race in the world and therefore the more of the world (they) inhabited, the better it would be for the human race" (Nyangeni 19).

Southern Rhodesia, which is known today as Zimbabwe, is located in central southern Africa. In 1890 the first Developer made up of 180 men and some policemen arrived in Southern Rhodesia from the United Kingdom coming up from the Cape through a land which was to be full natives, who were no more than savages for them. They were travelling into unknown lands, for even though explorers and missionaries had been ahead of them, no one had yet settled as colonizers. During the epoch of discrimination and inequality in Southern Africa, racial inequality muzzled many black writers. It was the white authors that dominated the literary environment presenting their biased views on social and political concerns; the black authors positions were seen as unimportant and they were considered inferior to the white authors. Consequently, it was particularly tough for black writers to voice their experiences of living in a society saturated with oppression, prejudice and inequality.

Consequently, the colonizers were on this quest for the sake of Empire, Rhodes and the Queen, and "they were a pioneering breed, people who had to see horizons as a challenge" (African Laughter, Four visits to Zimbabwe: 3). promptly, a town was built, Salisbury, with a church, a hospital, a school and other facilities. As the Europeans began to settle, business-seekers started negotiations with the natives, who had little knowledge of the implications, signed their land away to the Rudd Concession which vindicated the occupation and the colonization of the country. Soon the natives found they had lost a great part of their land. As a result, they became labors and 

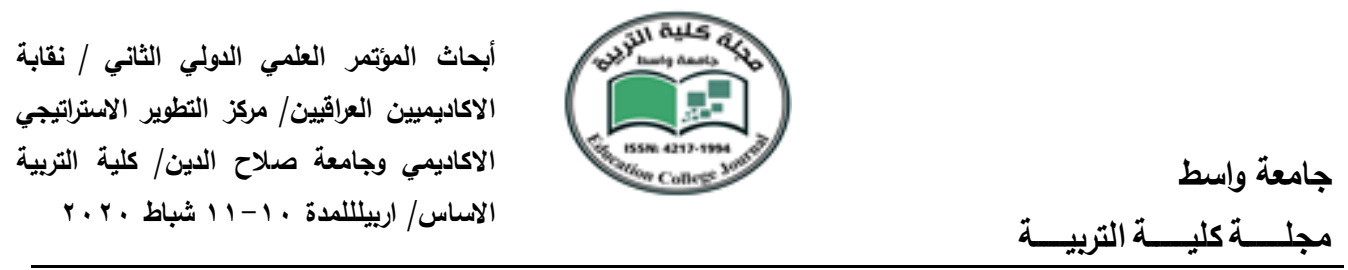

servants for the white community. The first violent reaction against the colonizers happened in 1896-97 with the Ndebele-Shona rising known as the First Chimurenga, their first national war of liberation. The making of Southern Rhodesia became a complex one as the white settlers attempted to indigenize themselves and the natives endeavored to make sense of their new position as a colonized people.

By the 1900s, Southern Rhodesia had recognized its borders and had as its neighbors Mozambique, South West Africa, Bechuanaland, Northern Rhodesia and the Transvaal. It was not surprising therefore that from the time of colonization and especially during the 1950s, organized African confrontation movements began to take shape and by the 1960s these became powerful forces flooring a hard road ahead for both blacks and whites and for the history of the country, a struggle which continued till today. Doris Lessing breathed within this environment for twenty-five years having arrived as a child of five in 1924 and having left in 1949, exiled, as a young woman of thirty. She wrote her first novel The Grass is Singing (1950) before leaving the country but was only able to have it published in London the following year.

\section{Apartheid and Racism in Rhodesia:}

The Africans were governed by a white government in which they were prohibited from practicing any rights. It was only the whites that were allowed to vote and elect the leaders for Rhodesia. Additionally decrees allowed for the unfair distribution of the land that provided farmers with nutrition where under these decrees, "6000 whites seized the best half of the land while the worst half was left to 600000 black peasant farmers" (Chung 211). Throughout the history of the settler occupation it has been possible for whites to impose the humiliation upon blacks, seemingly with pride, and certainly without regret. The sense of the unquestioned right to do this can be demonstrated by some quotations from white leaders at important stages of Rhodesian history. Rhodes admired Anglo-Saxon culture and believed that: 'We are the finest race in the world . . . and . . the more of the world we inhabit the better it is for the human race.' Sir Godfrey Huggins, who led 

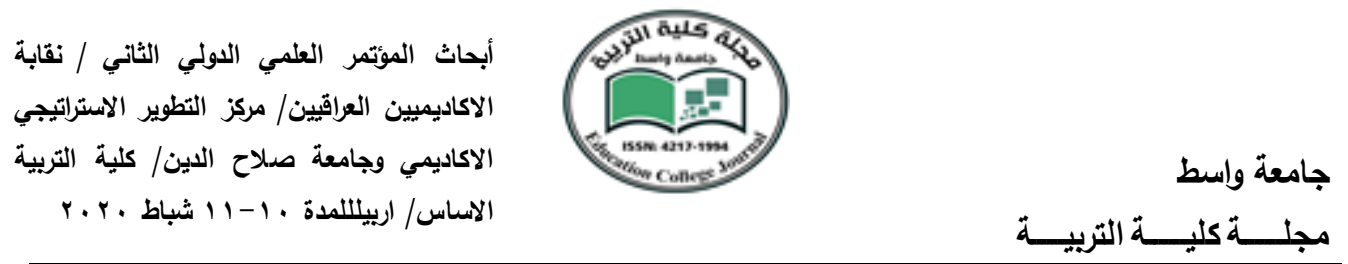

white Rhodesians through their most secure and prosperous years (1933-53), expressed what may be regarded as the classic description of the Rhodesian ideal for the relationship between the races (Austin 26).

Apartheid is an Afrikaans word meaning separateness. As the political ideology practiced in South Africa, it means territorial separation and separate administrative and social structures for whites and the various racial and tribal groups, but all under white control (Ibid 29). As white society and its economy depend on black labor, however, separation has to be selectively applied. Racial discrimination and separation are essential features of apartheid but, as the Rhodesian example shows, can be achieved by less formal social and economic structures of domination, and strengthened by social custom and legislation. The settler-dominated country created largely by the efforts of Cecil Rhodes and his followers is now called Rhodesia, and its present white inhabitants are called Rhodesians. Legally, however, it continues to be 'Southern Rhodesia', being still regarded by the United Nations and all its Member States as a colony of the United Kingdom, which is internationally responsible for the territory. The vast majority of the African population now refers to the territory as Zimbabwe, after one of the political systems which formerly flourished there. Rhodesia and Zimbabwe represent opposing ideals. The texts of Doris Lessing reflect and emphasize the unjust and divided societies of Rhodesia. The power and authority of race is of significance as human fate was verbalized and manipulated by a person's ancestry and appearance. The characteristics of a person's hair, complexion and facial features mediated every aspect of the African person's life. People were judged exclusively on external biological aspects of race, and these resulted their standards of living, and ultimately their racial inequality instigated the labeling and cataloging of black African writers in numerous ways. White authors and publishers dominated the literary environment, presenting their stereotypical views, while black authors were seen as unimportant and inferior to their white counterparts. It was tremendously difficult for black African writers to voice their views and experiences of living in a society pierced with oppression, prejudice and 

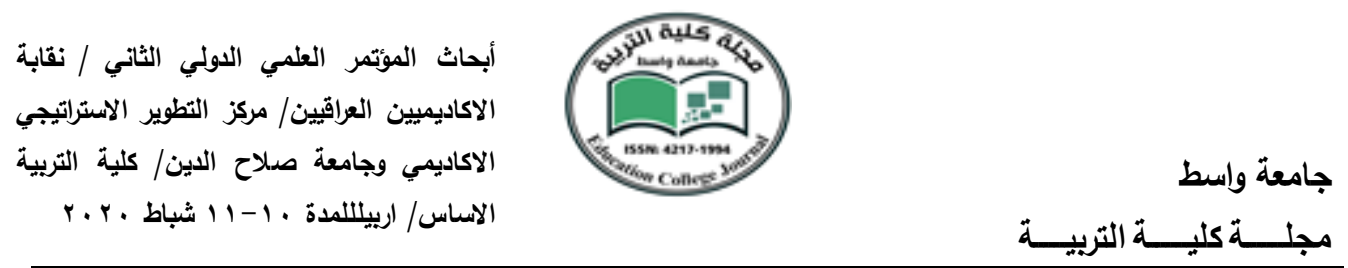

unequal economic and educational opportunities. The quieting of black writers is reinforced in the fact that by the time Doris Lessing was of worldwide fame, no writer had yet emerged among the black population of five to six million, whose fate was entirely in the hands of 300000 white settlers in Rhodesia (Gerard 256).

\section{A Short Biography of Doris Lessing \& a Gist to Going Home:}

Doris Lessing was born in Kermanshah, Persia (present-day Iran), on October 22, 1919. After growing up in Rhodesia (now Zimbabwe), she moved to England and entered her writing career. Her first novel was published in 1950 The Grass is Singing and her 1962 novel The Golden Notebook turned her into a feminist role model. The author of more than 55 works covering fiction, nonfiction, poetry and opera, Lessing became the oldest recipient of the Nobel Prize for Literature in 2007, at the age of 88. She died in 2013, at age 94. (Biography.com Editors). Thus, Southern Africa 'Rhodesia' is the motif of Doris Lessing's total literary production as well as of her whole life experience. The most ground-breaking of contemporary British writers and the recipient of more than twenty literary prizes and awards. After a sevenyear absence returned to Southern Rhodesia in 1956 in order to re-examine the country of her childhood. During her journey, she had been under constant scrutiny, by the political police. Due to her political views, her presence was declared undesirable in both Southern Rhodesia and Africa. The experiences of her journey are narrated in her book Going Home (1957), in part a personal narrative, partway as a travel notebook. It was only after Rhodesia had gained its independence in 1980 that she was able to return to that part of Africa. Lessing witnessed the deceitfulness of discriminatory mechanism in colonial Africa.

\section{Going Home's Depiction of Social Inequality \& Biasness:}

Zimbabwean literature is defined as the works of Zimbabwean Africans who through their prose and poetry have articulated the human and cultural objectives of the nation and its people."'(SayceTabex Encyclopedia Zimbabwe 

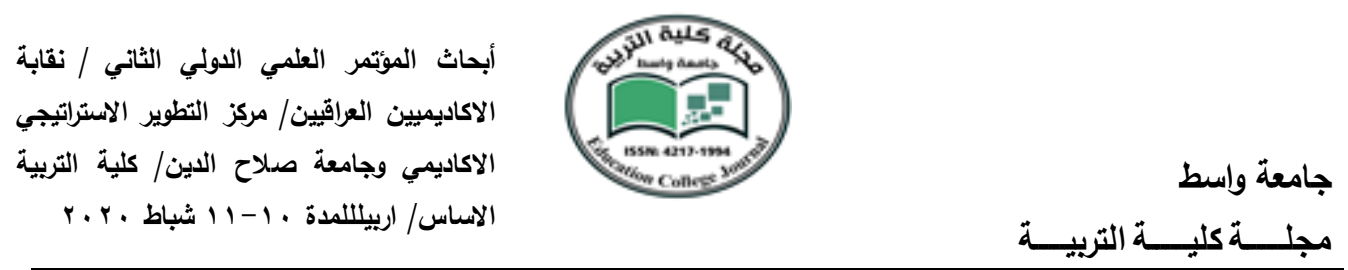

219) Doris Lessing and Arthur Shearly Cripps do not fall in the category of Zimbabwean writers according to this definition because they are white writers. Despite the fact, in their writings the Blacks do not express their avowed targets for a new nationhood. They either look back to tradition and the past with nostalgia or aspire to lodge a more central place in the settler society, which had marginalized them for so many years as they lived injustice and breathed oppressions.

Moreover, it was in Rhodesia Lessing's life was marked by the culture of colonialism and of white settler farmers (Gikundi 287). Doris Lessing had to escape the society based on unequal opportunities thus, in 1949; she left Rhodesia and moved to England. It is important to note that: "Although Doris Lessing has lived in England since 1949, she is considered an African author because the twenty-five years spent growing up on a small farm in what was then Southern Rhodesia had such an impact on her writing" (Sizemore 282). Lessing returned to visit Rhodesia in 1956, it was henceforth that she was declared a prohibited immigrant and was banned from returning to the country because of her disapproval to colonial rule in the region (Gikundi 287). Although Lessing lived in England, most of her writings are constitutively formed about Rhodesia due to its atmospheres, which became the source of her political involvement and memoir too. In Going Home, which is an account of her return in 1956 to Rhodesia, Lessing situates Rhodesia as a place where she experiences the sense of exile and alienation. . At the opening of her journal, she acknowledges that after a year of estrangement in London, a "nightmare city" (7), and how she feels comforted once she is back at Africa, however, during her journey, she encounters, interviews different "types" (12) of Rhodesians. She examines some of the detrimental effects of the Federation, and she chooses the color-bar as a tool to demonstrate the social injustice. Her aim is on the one hand, to designate that "Africa belongs to African", and on the other to show the fact that it is impossible to combine or link people who hate each other. 

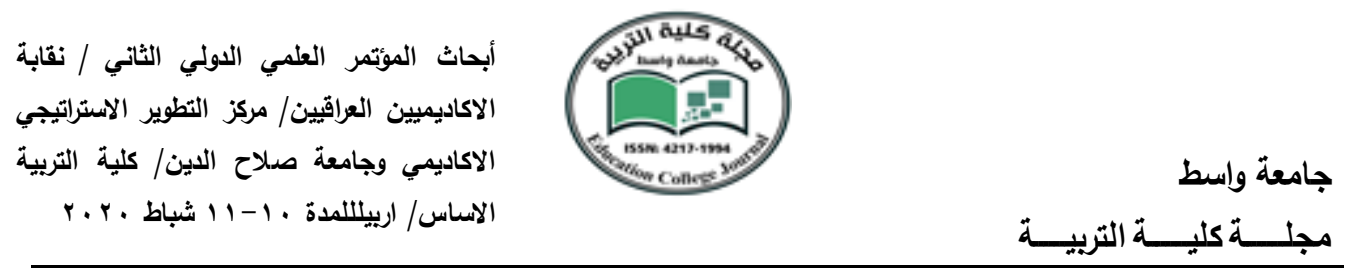

Thus, Lessing's memory and nostalgia becomes the centerpiece of her journalism. The structure of Southern Rhodesian society is built upon oppression, an oppression based entirely on race. Lessing describes how she is content due to her visit to house in which she was brought up "now for the first time I was really home" (30), which shows her state in living in exile, and now she longs for the place where she was brought up even within the course of the novel she composes some beautiful poems that reflect her state of mind. One of them is called "The Lilies" in which she describes her mourning at Southern Rhodesia

Somehow I thought of flowers

Flowers! That bad smell!

I looked: down lanes, past houses-

There, behind a hoarding,

A rubbish-heap, soft and wet and rotten.

So, this wistful desire and loathing desire at the same time conveys her nostalgia to her old environment and the current state of the country, full of hatred, discrimination, and injustice. Edward Said in his essay "Reflection on exile" shows the concept of 'home' "the exile knows that in a secular and contingent world, homes are always provisional. Boarders and barriers which enclose us within the safety of familiar territory, can also become prisons, and are often defended beyond reason or necessity" (147) Therefore, throughout her journey she will be uncomforted, discontent, or even imprisoned. In Going Home, it is her personal disposition to become involved in day-to-day politics as a writer so, she insists on being a journalist first, to know more about Partnership, and second to pay for her expenses despite the fact that she was warned about being considered as an agitator by CID in the Union. She sees Southern Rhodesia as "self-consciously British" (51), and the federation with Northern Rhodesia and Nyasaland is still an affirmation of being British. For some hour she becomes "infected with optimism" (69) in Federation because the people who are "selling it" to her are convinced by it themselves. Therefore, Lessing shows the oppression or social injustice by investigating some aspects of life in Rhodesia. For instance, education is offered unfairly to the white children and the black ones. She says that most 

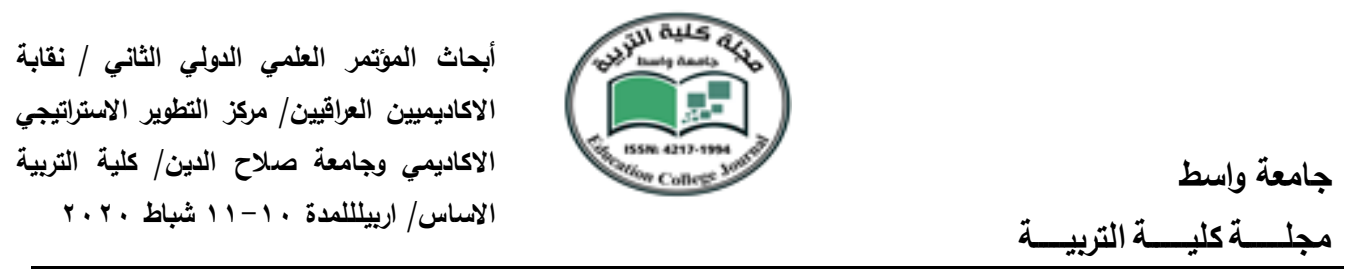

of the education is still in the hands of missionaries. Also, all the wealth of the country is created by white citizenry and whatever is "done" is in the favor of them. Education in Africa in Lessing's words is to "humour the spirit of white supremacy" (71); it is a mad dog lay sleeping which "perhaps it might die in its sleep!". What Partnership does is giving a few privileges, and raising the standards of a minority of Africans above their fellows. When Lessing's notes about Dixon imprisonment get published in the Tribune, she is arrested because she was telling the people the truth about the Federation. She is put in general prison for two weeks and the rest four months in solitary confinement which is another kind of exile and solitude. However, what is worse is that even in prison there is color discrimination. The white prisoners are in one place with good food, and they are not treated badly. Before leaving the prison, she takes the socialist's instructions in consideration, and believes them to be an example of "how a color-bar society pressures economic thinking into strange, strange shapes (75). The white population, in the racist regimes of Rhodesia was known to portray aggressive and fierce characteristics towards the black individuals in society, abusing them physically and emotionally. The black African people had contact and relations with the white world as they provided domestic labor and labor forces for these cruel people. As a result of this, the blacks were subjected to the malicious attitudes of the whites, thus, reinforcing this behavior in the psyche of the blacks. It is for this reason that the blacks adopted the hostile attitude of their superior. Lessing's extended idea enables her to see beyond the false colonial myths of white superiority and the necessity of the blacks and the white remaining separate. Her African stories arise from a kind of irony produced by perceiving the gap between the myth and African reality. Throughout her work, she acknowledges the African right to Africa, and condemns the white colonialist's ignorance of their complex tribal history, and culture, threatened with destruction. Africa as opposed to its colonial regime was for her a vigorous source of imaginative nourishment. It was her air, her landscape, and above all her sun. She, however, knew that "Africa belonged to the African, the sooner they took it, the better" (Lessing). Lessing's African writings offered both a satire of the disintegrating Empire's 

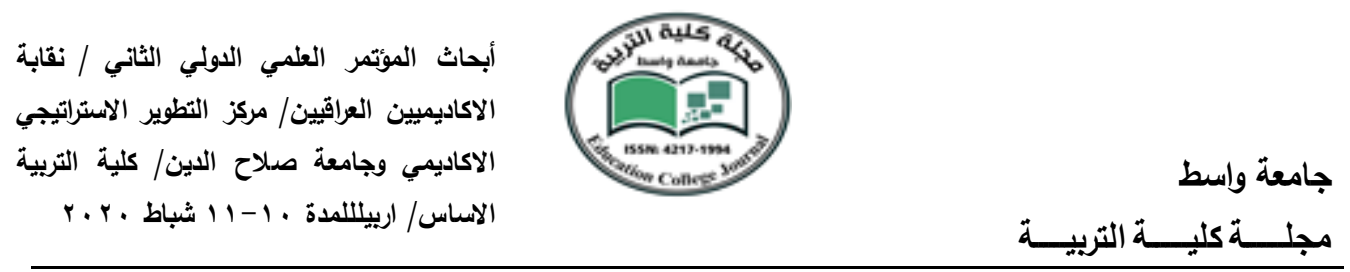

expatriate delusions and of the sickness of dissolution of white supremacy. That is to say through the attempts to change Southern Rhodesia from tribal system to industrial one, but the paradox of Northern Rhodesia and Nyasaland is the Africans are suitable for advancement, to acquire skills, etc. But because of the Federation, because of the fear of Southern Rhodesian and South African systems "if the price of every entering the modern world ..., then we prefer to remain what you call backward" (212).

Also, another instance is when at the Jan Smuts airport Lessing's name is mentioned on the blacklists of the police, and immediately told that is a prohibited immigrant. She has no romantic views towards politics because she believes that the regime in South Africa prevent people from rebelling and keep them as "helots" (80) through a very efficient system "apartheid" which "keeps the country backward and will slowly corrupt it", and by this "white civilization" will become more and more brutal and warped.

In addition, women in come to be seen as commodities. This phenomenon is discussed among a group of Superintendents for the locations. The difference between the old type Native Department official and the new is clearly seen when they are talking about women. One of the officials shows how the men are dissatisfied with the women always quarrelling and complaining while the other says "married accommodation is much better than single, men marry 'spares' so as to get marriage certificate" (154), yet Dr. Holleman suggests that the women are not true prostitutes. Lessing in turn, shows that 'spare' is a phenomenon of industrializing Africa. Lessing refers the letter from an African to the African whose content is "prostitution is the gravest thing facing our community today" (155), therefore, to them marriage is "the end of profit-making career; it removes their freedom to go wherever they like" (155). Furthermore, class discrimination is shown through the disequilibrium in labor wages for example, an African laborer in Southern Rhodesia, earns about $£ 3$ or $£ 4$ a month, plus food and housing while a white artisan can earn $£ 70$ or $£ 80$ a month, and on the Coper Belt an African earns 6 to 10 a month while white workers $£ 150$ to£ 200 which is impossible for an employer to pay "white" rates. Lessing explains that around the "white" centers African townships and 

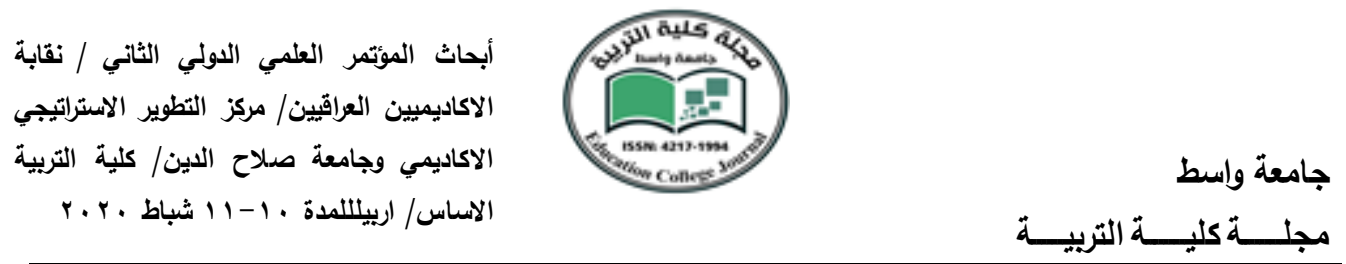

squatters' camps are existed, and these are completely segregated. Africans cannot use restaurants, hotels, or bars in the areas. An African should have various "passes" like: his registration certificate, his certificate of residence, of work, and if he is employed as a servant, he must have a "pass" for visiting. In addition, Lessing suggest to examine a case like Rhodesia, one should have a look from the inside not from the outside "most politicians and journalists do their judging from outside only. And most of the people on the spot are lost in a violent emotionalism" (238) so, when Federation is dissolved, the nationalist movements of Northern Rhodesia and Nyasaland are fed, fuelled, powered by the feeling of having been betrayed, "sold out" (239). Even Rhodesia's regime is similar, but as Lessing explains "that country has never been able to see the truth about its own nature" (239), therefore, the Rhodesian at that time liked to think of themselves as 'British', meaning good, kind, decent, civilized, and not 'Afrikaans' which means crude, backward, bad, again this shows that years of persecuting have disciplined these people that they themselves have self-loathing or self-denial feelings, As a suggestion made by her friend, Lessing should have another look on the Land Apportionment Act. She observes that there are hotels and restaurants on a civilized level, but there is nothing in Southern Rhodesia. It is worth mentioning that the Land Apportionment Act is the basis of Southern Rhodesia policy. It is an act of taking away land from the Africans and giving it to the Europeans. In Southern Rhodesia 46 per cent of the land remains to the Africans whereas in Northern Rhodesia about 5 per cent has been taken from them. The Land Appointment Act is "not so much a piece of legislation as an octopus" (240). The White Commission's ideology led to the imposition of Land Apportionment Act in 1930. This Act was even worse than the various segregation acts passed in the prejudiced union of South Africa. Doris Lessing herself commented on it:

The Land Apportionment Act is the basis of Southern Rhodesia policy, as the Group Areas Act is in the Union. In both countries land is parceled out into areas called Native and European. In Southern Rhodesia only 46 per cent of the land still remains to the Africans. (Whereas in Northern 

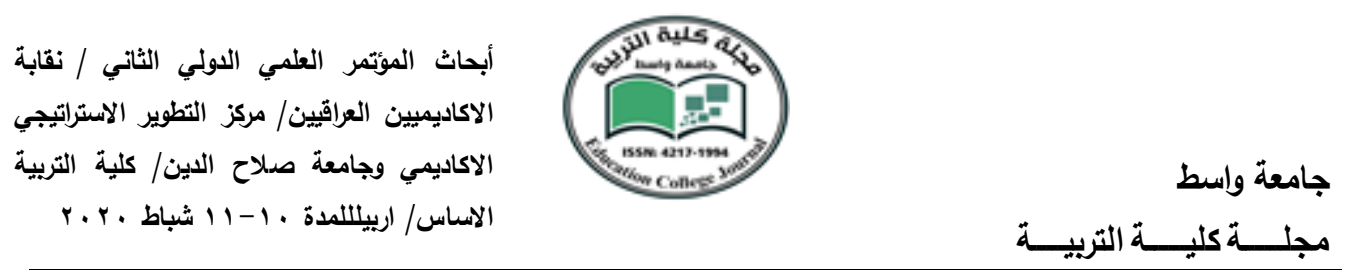

Rhodesia and Nyasaland about 5 per cent has been taken from them). Since Partnership, this basic segregation has been hardened, not relaxed. Thousands of Africans have been forcibly moved off 'European' land, where they had been living for generations, into Reserves. (The Africans form 95 per cent of the population; thus half the land is held by the white 5 per cent). (Lessing 125)

It is obvious how racism in Southern Rhodesia had more of a systematic cause as its roots lay in a powerful combination of ideology and material interest (McCulloch 67). "It is an ensemble of material practices where prejudices are institutionalized in administrations, legal systems and labor markets" (McCulloch 69). McCulloch uses the term "racial formation" to exemplify that racial categories are created, inhabited and altered over time and place and are primarily about power (McCulloch 69). Michel Foucault validates the relations of power in his quote:

Relations of power are not in themselves forms of repression. But what happens is that, in society, in most societies, organizations are created to freeze the relations of power, hold those relations in a state of symmetry, so that a certain number of persons get an advantage, socially, economically, politically, institutionally. And this totally freezes the situation. That's what one calls power in the strict sense of the term: it's a specific type of power relation that has been institutionalized, frozen, immobilized, to the profit of some and to the detriment of others. (Foucault 28)

Accordingly, race is regarded as a social rather than a biological construction in this theory; it is even valid to the society at present as, despite the continuous efforts to eliminate race and gender subjugation in society, these remain unrelenting issues, evidenced in the recent intolerant attacks. Thus possible endorsements for improvement in race relations will be offered through a consideration of this ethnic literary theoretical framework. Frantz 

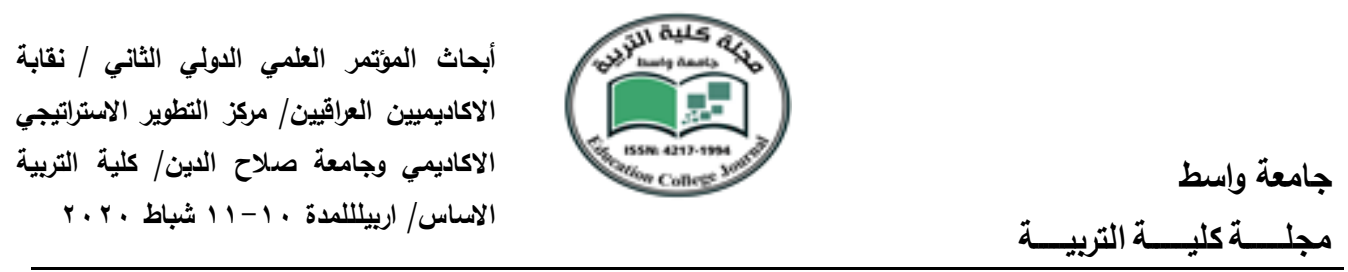

Fanon was interested in racial differences, "and his thinking brings together insights into psychology and a concern for the effects of domination on subjugated peoples" (Fanon, "The Negro and Psychopathology" 462). He scrutinizes the effects of white authority on the subjugated black people of society by incorporating his knowledge of psychology and the working of the human brain into the argument. Fanon affirms that "there are close connections between the She criticizes the bits of law that form it and makes fun of them that they were just ridicules and absurd that temple full of lawyers will be needed to make of that Act. She adds that there is no law passed in Southern Rhodesia that does not, directly or indirectly, discriminate between white and black, thereby making 'self-government' invalid by definition. The structures of the family counterparts. The intimidating and brutal attitude of "The Other" is then incorporated into each facet of the black's life, as it is through the disguise of a white person that offers the black person a feeling of importance and worth. A black male's attitude and power, in the imitation of a white man, is then reinforced in his conduct towards the black women in his society where he portrays his mimicked violent and aggressive attitude. Oppression and abuse of the black women by the black men in their lives, mirroring the poor manner in which the black men themselves were treated by the white citizens in society. The psychological stress experienced by Southern African citizens during the imbalanced society rife with power and discrimination issues, can also be scrutinized by investigating the emotional trauma experienced by both powerless victims and authorial perpetrators of the cruel African society.

Foucault points out the density of the term power and he contests that power is one's ability to impede people from doing what they want (119). Rather, Foucault's way of looking at power is that it is everywhere in society and in all forms of relationships: "It needs to be considered as a productive network which runs through the whole social body" (119). Thus, as Loomba shapes it when discussing Foucault's notion of power, "it is part of daily action, speech and everyday life" (50). Power, according to Foucault, also creates and restricts behavior at the same time (119), a notion that will be used when discussing how the discourse puts the colonizers in a favorable position over 

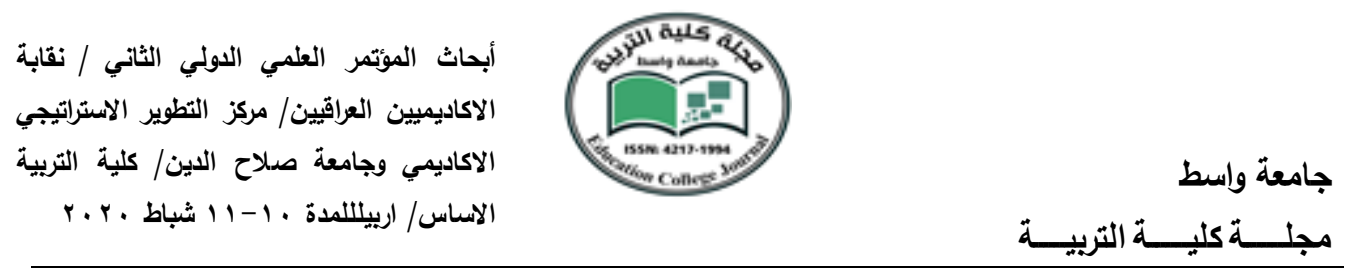

the black population while it, at the same time, limits how they as British colonizers are allowed to live like all power structure systems of its kind it is fragile and only functions as long as everyone plays their part and sticks to the assigned task that has been given through the discourse. Ashcroft, Griffiths and Tiffin state that "the growth of empires was accompanied by the capacity to confirm European notions of utility, rationality, discipline as truth" (64). Therefore, this is what every white settler has to do and what the black people have to follow. If enough people challenge the system and its power structure, by for example stepping out of line, not following the orders that they have been given, the whole system can very well collapse. It is by being undisciplined and irrational in his farming, thus not making any profit; Moreover, in some areas certain Africans are highly paid to spy, inform, insinuate Lessing states that there is no success in political movements in South Africa even when she goes to Zambia for the Independence Celebrations "nothing succeeds like success"; the Nationalist leaders, Kaunda, are reviled by the whites, and the Africans are rioting, stoning white cars, challenging the color bar everywhere. One can only behold injustice and nothing else in such colonial lands even when the journalists are asked why the keep quiet about what they know of oppression, torture, and savagery of the machinery of apartheid they reply they will lose their jobs so corruption has invaded everywhere. Lessing admits when she wrote Going Home, she was a communist, the conviction that there was something wrong about the distribution of rights, and the difference in material conditions between the two races made her a Marxist, but she did not remain so, however, holding a party card was good for her. "I am grateful to the Communists for what they taught me: particularly about power, the realities of political power" (247). Through Africa and her experience of its life in the most sympathetic years of her life. Lessing's childhood observation led her not only to an energetic compassion for the black Rhodesians, but also to a keen analysis of white colonialist attitude. She documented hypocrisy in the "civilized" British at an early age. She could see through the evil design of the colonial meta-society held together by unanimous commitment to extend the subordination of the black population. She knew it clearly and hated it instinctively. Lessing saw 

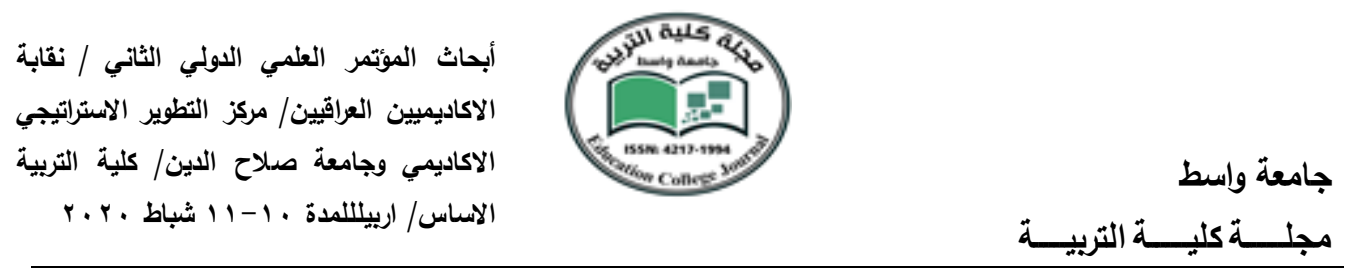

obviously the real face of the unjust society of White settlers in South Rhodesia, which had pursued "...the policy of treating the land of Southern Rhodesia as though it had passed entirely out of native ownership and had become the property of the Company's shareholders. It has divided the land into two main categories, 'alienated and unalienated" (Morel Blackmen's Burden 49). In Going Home Lessing observes a society under the weight of its unsustainable contradictions has to collapse "the price of liberty is, more than ever, eternal vigilance, which is why I think the most valuable citizens any country can possess are the troublemakers, the public nuisances, the fighters of small, apparently unimportant battles" (252).

\section{Conclusion:}

Lessing through her journal tries to scandalize the regimes that ruled Southern Africa. In an attempt to construct a text out of her memoir and native land, she stands as a documentarist of a specific area in a particular era of South Africa. She works in two directions one as a real observer who lives the events, and two as a good writer who writes has fidelity to her land, and does not want to erase its memory. Going home is the investment of Lessing's memoir and emotion in order to immortalize a history of colonized land. Lessing's fiction comes from her understanding both of the prevailing myth and of the forces, which challenged them. She grew up in Southern Rhodesia and she had a collective memory in the culture she describes. The picture she gives of the white dominated society in the nineteen thirties and the forties is realistic and convincing. Her early education was based on an acceptance of the colonial mythology. Her self-education developed an increasing awareness of the mythopoeic process. She understood the severe limitations of colored society, which is formed and kept unified by maintaining its own narrow boundaries. But Lessing has realized the feat of imaginatively stepping outside its borders; her fiction shares her unscrambling from the narrow colonial myths. 
أبحاث المؤتمر العلمي الدولي الثاني / نقابة

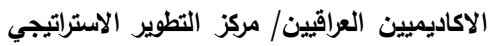

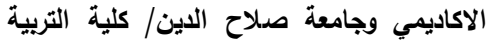

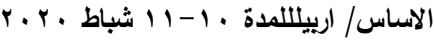
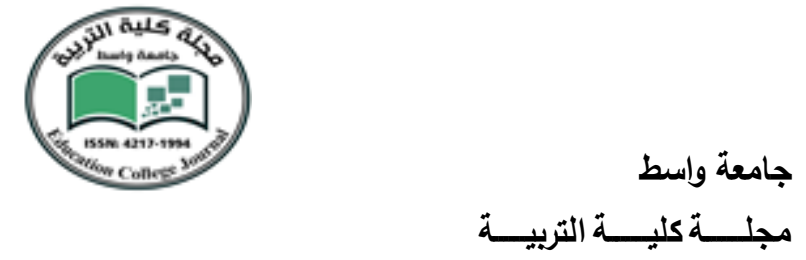

WORKS CITED

Ashcroft, Bill, Gareth Griffiths and Helen Tiffin. Post-Colonial Studies: The Key Concepts.

London: Routledge, 2007. Print.

Austin, Reginald. Racism and Apartheid in Southern Africa 'Rhodesia', Unesco Press, Imprimeries Réunies, Lausanne. Paris, 1975. Print

Chung, Fay. "Education With Production Before and After Independence." Turmoil and Tenacity. Ed. Canaan Banana. Harare: The College Press, Ltd., 1989. Print.

Fanon, Frantz. "The Negro and Psychopathology." Literary Theory: An Anthology. Eds. Julie Rivkin and Michael Ryan. Oxford: Blackwell Publishing Ltd, 1998. 462467. Print.

Foucault, Michel. "Truth and Power." Power/Knowledge: Selected Interviews \& Other Writings 1972-1977. Ed. Colin Gordon. New York: Pantheon, 1980. Print.

Gerard, Albert. European-Language Writing in Sub-Saharan Africa, Volume 2. Budapest: Akademiai Kiado, 1986. Print.

Gikundi, Simon. "Lessing, Doris." Encyclopedia of African Literature. Ed. Simon Gikundi. London: Routledge, 2003. Print.

. Katherine Sayce et al Tabex EncyclopaediaZimbabwe. ed. Harare: Quest Publishing, 1987.Print.

Lessing, Doris. Going Home. New York: Harper Perennial, 1957. Print.

Loomba, Ania. Colonialism/Postcolonialism. London: Routledge, 1998. Print.

McCulloch, Jock. Black Peril, White Virtue: Sexual Crime in Southern Rhodesia, 1902-1935. Indiana: Indiana University Press, 2000. Print

Morel, E.D.The Black Men's Burden.New York: Monthly Review Press, 
أبحاث المؤتمر العلمي الدولي الثاني / نقابة

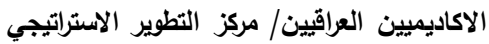

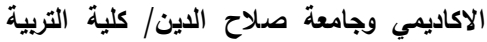

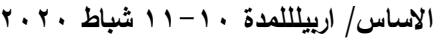

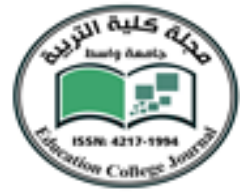

جامعة واسط

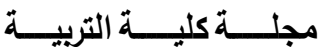

1969. Print.

Nyangani, Wellington. African Nationalism in Zimbabwe. Washington D.C.: University Press of America, 1978. Print.

Said, Edward. "Reflections on Exile

Sibanda, Eliakim. The Zimbabwe African People's Union 1961-1987: A Political History of Insurgency in Southern Rhodesia. World African Press Inc., 2005. Print.

Sizemore, Christine. "Doris Lessing." Postcolonial African Writers: A BioBibliographical Critical Source Book. Eds. Pushpa Naidu Parekh and Siga Fatima Jagne. Westport: Greenwood Publishing Group, 1998. 282-296. Print.

www. Doris Lessing Biography, Biograpghy.com editors. Retrieved on 23/3/2019 